\title{
Analysis of efficiency of biodiesel production in a laboratory scale using a Network Data Envelopment Analysis - DEA methodology
}

\author{
Análise de eficiência de produção de biodiesel em escala laboratorial utilizando a \\ metodologia Network DEA-Data Envelopment Analysis
}

Rafaela Ferreira Lopes, João Carlos Correa Baptista Soares de Mello e Ivenio Moreira da Silva

Universidade Federal Fluminense, RJ, Brasil

rafaelafl@id.uff.br; joaocsmello@gmail.com; ivenio@vm.uff.br

\begin{abstract}
This study aims to evaluate the biodiesel production performance in laboratorial scale, applying the Network Data Envelopment Analysis (DEA) model. This model allows to estimate the efficiency and volumes of different kind of oils used in tests. The input and output variables were obtained experimentally at the Laboratory of Post-Harvest Technology and Processing of Agricultural Products LTPC of the Department of Engineering of the Federal Fluminense University. It was made an efficiency analysis in networks, separated in three stages. In the first stage, were used as inputs: oil, alcohol, catalysts and glycerol (undesirable output) in order to analyze the crude biodiesel production (first stage output). In the second stage, the intermediate product generated in the first stage, was used as input, in addition to acid and deionized water, having as output the washed biodiesel. And, in the third stage, the intermediate product generated in the second stage, washed biodiesel, was used as input, with the final product being the washed and filtered biodiesel. The results suggested that for the production stage, the first one, the smaller volumes were more efficient, but for the global stage the most efficient was the DMU Canola 200mL. The model presented scale returns and a raising scale factor, for all kinds of oil.
\end{abstract}

Keywords: Efficiency; Oils; Volumes; Stages; Network DEA

\section{Resumo}

O objetivo deste trabalho é analisar o desempenho da produção do biodiesel em escala laboratorial, aplicando o modelo Network Data Envelopment Analysis - DEA. Com este modelo, foi possível avaliar a eficiência dos tipos de óleos e seus volumes. Para isso, foram consideradas variáveis de insumo e produto obtidas experimentalmente no Laboratório de Tecnologia Pós-Colheita e Processamento de Produtos Agrícolas - LTPC do Departamento de Engenharia da Universidade Federal Fluminense, sendo esta análise dividida em três estágios, ou seja, uma análise de eficiência em redes. No primeiro estágio, foram utilizados o óleo, álcool, catalisador e glicerina (output indesejável), entradas utilizadas para analisar a produção de biodiesel bruto (output). Já no segundo estágio, o produto intermediário gerado no primeiro estágio foi então utilizado como entrada, além do ácido e água deionizada, tendo como saída o biodiesel lavado. E, no terceiro estágio, o produto intermediário gerado no segundo estágio foi utilizado como entrada, tendo como produto final o biodiesel seco e filtrado. Os resultados sugeriram que para o estágio 1, o de produção, os menores volumes foram mais eficientes, porém para o estágio global o mais eficiente foi a DMU Canola 200ml. O modelo apresentou retornos de escala.

Palavras-chave: Eficiência; Óleos; Volumes; Estágios; Network DEA 


\section{INTRODUCTION}

The adoption of different sources of renewable energies is linked to environmental, social and economic sustainability issues, as well complementary of non-renewable energies.

Considering the fact that biodiesel has physical properties similar to petroleum diesel, and for strategic reasons, many countries around the world are exploring and using biodiesel commercially, mixed with petroleum diesel, such as USA, Japan and India (LIN; LIN; HUNG, 2006; SANTACESARIA et al., 2012). Even with a higher production cost than petroleum diesel, many governments subsidize their production. In Brazil, for example, was established the percentage of $8 \%$ of biodiesel in commercial diesel mixture. This way, different sustainable sources of liquid fuels, such as biodiesel, have been the subject of incorporation studies into public policies, where biofuels production plays a significant role (SORDA; BANSE; KEMFERT, 2010).

The biofuels (ethanol and biodiesel) scene in Brazil have stood out by reasons currently wellknown: economic arguments, including the oil price oscillation in the last thirty years; the aid that biodiesel causes in the international commercial balance, through the reduction of petroleum derivatives imports, besides the improvement of final products value, by not exporting fresh grains, crushing and producing oil and bran that is used inside the country; environmental arguments, such as reduction of pollutants emissions (like sulfur and carbon monoxide) and the greenhouse effects attenuation and social arguments, such as the opportunity to reduce regional inequalities. These arguments contribute to the introduction of biodiesel into the Brazil's energy matrix, by the creation of the National Program of Production and Use of Biodiesel (PNPB). These issues have led researchers to study alternative fuels production from renewable energy sources, that are environmentally acceptable.

The present article, therefore, aims to show an analysis of soybean, canola, sunflower and corn crops as raw materials for biodiesel production, considering each stage of the production process and analyzing the performance and efficiency of each stage.

It was used the non-parametric technique known as Network Data Envelopment Analyzes (DEA) because of its ability to obtain trustworthy results, with the possibility of comparisons between several units, providing reliable information about its performance. Thus, an application of the DEA methodology was carried out to evaluate the biodiesel production efficiency in laboratory scale.

\subsection{Biodiesel}

Biodiesel is a biodegradable, non-toxic fuel, derived from renewable sources such as vegetable oils and animal fats (MATH; PREM; CHETTY, 2010), being produced from the transesterification and/or esterification of vegetable fats or greases (ANP Resolution $n^{\circ} 45$ from 08/25/2014; SILVA et al., 2015; OLIVEIRA; COSTA, 2006).

Biodiesel is perfectly miscible to diesel oil, physically and chemically similar to it and can be used in diesel-cycle engines without the need for any adaptations (LORA; VENTURINI, 2012; XIE; LI, 2006). The use of biodiesel come with a wide range of technical and safety advantages and is therefore an excellent alternative to petroleum diesel.

The oils and fats are basically formed by triglycerides (REDÁ; CARNEIRO, 2007) and there is a large variety of oleaginous plants that are potential sources of vegetable oils viable for biodiesel production. 
In Brazil, the raw material options for biodiesel production are peanut, cotton, castor oil, soybean, sunflower, sesame, canola and palm oils. In addition to these alternatives, but with a lower technological domain, Babassu, Jatropha, Macaúba and Oiticica can be cited as a source of raw material (COSTA NETO et al., 2000; FERRARI; OLIVEIRA, 2005; GRIMALDI et al., 2005).

The vegetable oil is the most technically desirable oil source for the production of biodiesel because it is a clean raw material, with constant composition, easy filtration and practically free of water (KARMAKAR; KARMAKAR; MUKHERJEE, 2010).

Different processes, such as cracking, esterification, hydro-esterification or transesterification (SILVA; FREITAS, 2008), can obtain Biodiesel. The most commonly biodiesel production process is the transesterification of triglycerides, where the vegetable oils and animal fats are mixed with an alcohol (usually methanol or ethanol) in the presence of a catalyst (usually alkaline) to form mono alkyl esters, in larger amount, that make the biodiesel and glycerol (SCHUCHARDT; SERCHELI; MATHEUS, 1998; ZAGONEL e RAMOS, 2001). For the transesterification reaction to occur successfully, it is necessary to control the reaction conditions, i.e.: alcohol type, molar ratio oil:alcohol, reaction temperature and time and catalyzer kind and amount (SANTOS et al., 2017).

\subsection{DEA Network- Data Envelopment Analysis}

The Data Envelopment Analysis (DEA) is a non-parametric technique that uses mathematical programming to evaluate the relative efficiency of productive units (also called DMUs - decisionmaking units). It was developed by Charnes, Cooper and Rhodes (1978), starting from the concept of efficiency developed by Farrell (1957).

The DEA model takes into account that the DMUs are subject to homogeneous production processes. The basic principle is to calculate and compare the performance of these units, with perform similar tasks, considering the relationship between the weighted sum of what is produced and the resources consumed by the evaluated unit, taking into account all the others DMU in the sample.

Traditional DEA models evaluate the performance of each DMU, considering the production as a "black box" where inputs / inputs are transformed into outputs / products. In many applications, a DMU is composed of several processes, which correspond to several levels or production stages. The DEA network establishes relationship flows between the variables and generates a score of total efficiency, as well a score for each dimension or process that develops inside each DMU (divisional score) (DE CASTRO LOBO et al., 2010). When the internal structure of a system is considered, the exogenous inputs can be used directly by all the processes, and the outputs of each process can be the final results of the system or the intermediary products to be used by other processes in the production.

In order to incorporate the interaction between the stages, Kao and Hawang (2008) proposed the fractional Network DEA relational model based on the CCR DEA model. The model allows to obtain the global efficiency $\left(E_{k}\right)$ and the efficiencies of each stage $\left(E_{k}^{1}, E_{k}^{2}\right)$, where $u_{r}, v_{i}, w_{d}$, are the multipliers of variables, $n$ is the number of DMU's and $x, y, z$ are the input and outputs a values and intermediate variables. The multiplicative method was developed based on the CCR model with inputs orientation. Similarly, this model can be developed based on the same model with outputs orientation. In this paper we present the CCR model, with output orientation, described in the linearized Equations 1 to 8. 


$$
E_{k}=\min \sum_{r=1}^{s} x_{r k} u_{r}
$$

s.a.

$$
\sum_{r=1}^{s} y_{r k} u_{r}=1
$$

$$
\begin{aligned}
& \sum_{r=1}^{s} y_{r k} u_{r}-\sum_{i=1}^{m} x_{i j} v_{i} \leq 1 j=1, \ldots, n \\
& \sum_{d=1}^{D} z_{d j} w_{d}-\sum_{i=1}^{m} x_{i j} v_{i} \leq 1 j=1, \ldots, n \\
& \sum_{r=1}^{s} y_{r j} u_{r}-\sum_{d=1}^{D} z_{d j} w_{d} \leq 1 j=1, \ldots, n
\end{aligned}
$$

$$
u_{r} \geq \varepsilon r=1, \ldots, s
$$

$$
v_{i} \geq \varepsilon i=1, \ldots, r
$$

$$
w_{d} \geq \varepsilon d=1, \ldots, D
$$

The symbol $\varepsilon$ is an infinitesimal non-Archimedean number (CHARNES; COOPER, 1984; CHARNES; COOPER; RHODES, 1978), used to avoid division by zero.

The internal stages efficiencies are obtained dividing the sum of the respective inputs products and their multipliers by the sum of the outputs product and their multipliers. Denoting by $v^{*}, w^{*} e u^{*}$, the optimal weights provided by the model, it is possible to obtain the efficiency indices $E_{k}, E_{k}^{1}, E_{k}^{2}$ described by the Equations 9 to 12 :

$$
\begin{aligned}
& E_{k}=\frac{\sum_{r=1}^{s} y_{r k} u_{r}^{*}}{\sum_{i=1}^{m} x_{i k} v_{i}^{*}} \leq 1 \\
& E_{k}^{1}=\frac{\sum_{d=1}^{D} z_{d k} w_{d}^{*}}{\sum_{i=1}^{m} x_{i k} v_{i}^{*}} \leq 1
\end{aligned}
$$




$$
\begin{aligned}
& E_{k}^{2}=\frac{\sum_{r=1}^{s} y_{r k} u_{r}^{*}}{\sum_{d=1}^{D} z_{d k} w_{d}^{*}} \leq 1 \\
& E_{k}=E_{k}^{1} x E_{k}^{2}
\end{aligned}
$$

According to Gomes Júnior et al. (2014), for a unit to be efficient in Network DEA models, it must be efficient at each stage. Thus, it may not occur a fully efficient DMU.

\section{METHODOLOGY}

It was used the Network DEA presented by Kao and Hwang (2008), considering the production process and the sub processes separately, in different stages, aiming to compose the efficiency of the biodiesel production process in the laboratory.

The first stage corresponds to the production of crude biodiesel by the transesterification reaction. The following stages are related to the purification of the crude biodiesel, with the second stage corresponding to the acid wash and the third stage to the drying and filtration stage. It was compared four types of oils (canola, sunflower, soy and corn), varying in four different volumes $(50 \mathrm{ml}, 100 \mathrm{ml}, 200 \mathrm{ml}$ and $400 \mathrm{ml})$. The following materials and reagents were used:

MATERIALS: Becker of $100 \mathrm{ml}, 400 \mathrm{ml}$ and $500 \mathrm{ml}$; electric heating plate with magnetic stirring; thermometer (scale till $100^{\circ} \mathrm{C}$ ); $100 \mathrm{ml}$ and $250 \mathrm{ml}$ beakers; decantation funnel; precision balance; 50 $\mathrm{ml}$ pipette; protective equipment; greenhouse.

REAGENTS: canola, soybean, sunflower and corn oils; anhydrous methanol $\left(\mathrm{CH}_{3} \mathrm{OH}\right)$; sodium hydroxide $(\mathrm{NaOH})$; hydrochloric acid $(\mathrm{HCl})$; deionized water.

The experiments were conducted at the Laboratory of Post-Harvest Technology and Processing of Agricultural Products - LTPC of the Engineering Department of the Fluminense Federal University.

In relation to the raw materials, it was not necessary to make any pre-treatment, since they presented adequate conditions for the reaction of transesterification. With the raw materials free from impurities, the production of biodiesel started.

The biodiesel obtaining process initiated by taking the raw material to a becker and heating to $60^{\circ} \mathrm{C}$ in the greenhouse. The volumes chosen for the production of biodiesel with canola, sunflower, corn and soybean oils were: $50 \mathrm{ml}, 100 \mathrm{ml}, 200 \mathrm{ml}$ and $400 \mathrm{ml}$, totaling 16 DMU's.

In another becker was added methanol (corresponding to $30 \%$ of the oil volume) added with $\mathrm{NaOH}$ catalyst (which corresponds to $1 \%$ of the oil volume). The mixture was placed in contact with the mechanical stirrer until the catalyst dissolved completely.

When the oil reached $60^{\circ} \mathrm{C}$ and the catalyst has dissolved, the oil was poured into the alcohol and the solution was kept for 60 minutes, at $60^{\circ} \mathrm{C}$ of temperature and with constant stirring. At the end of the reaction, the mixture was placed in a separating funnel, where rested for 24 hours in order to separate the glycerin. The glycerin and dirty biodiesel were removed and measured. Then, the biodiesel washing procedure was started. The glycerin produced was stored in a glass vial. 
After the glycerin decantation, it was removed and the methyl esters were washed in the same funnel using hydrochloric acid $\left(0.5 \%\right.$ of the volume of dirty biodiesel) and deionized water at $50^{\circ} \mathrm{C}$, at the rate of $30 \%$ of water for dirty biodiesel. Posterior of the water and acid addition, the stirring was carried out to promote a better impurities removal (unreacted alcohol, catalyst and soaps formed during the reaction). Subsequently, water and biodiesel were separated by decantation. The water was the densest phase and migrated to the bottom of the funnel, while the biodiesel remained at the top. After twenty minutes (time for separation of the two phases), the impure water was removed and then discarded. The washing procedure was performed three times. After washing, the biodiesel was oven dried at $105^{\circ} \mathrm{C}$ for two hours, this way all the water was evaporated.

For the mathematical formulation, the model was separated in three stages for the first process (biodiesel production). The initial input variables were oil $(\mathrm{ml})$, alcohol $(\mathrm{ml})$, catalyst $(\mathrm{g})$, and glycerin (ml).

This study aims were to evaluate the efficiency of biodiesel production, therefore, the glycerin was treated as an undesirable output. The undesirable output can be incorporated into the DEA models according to four main approaches, as discussed in Scheel (2001). In this study, was chosen to consider the undesirable product as an input. Gross or dirty biodiesel $(\mathrm{ml})$ is a first step output and also an intermediate output.

In the second step, which is the biodiesel washing, the input variables are: crude or dirty biodiesel $(\mathrm{ml})$, deionized water $(\mathrm{ml})$ and hydrochloric acid $(\mathrm{HCl})(\mathrm{ml})$. The second output of the process is the washed biodiesel $(\mathrm{ml})$, also considered an intermediate output.

Finally, at the third step, the washed biodiesel $(\mathrm{ml})$ is an input and the final output is the dried and filtered biodiesel (ml). The model allows to calculate each stage efficiency level of production. The figure 1 shows the scheme of the production process of a DMU.

Figure 1: Representation of a DMU Process

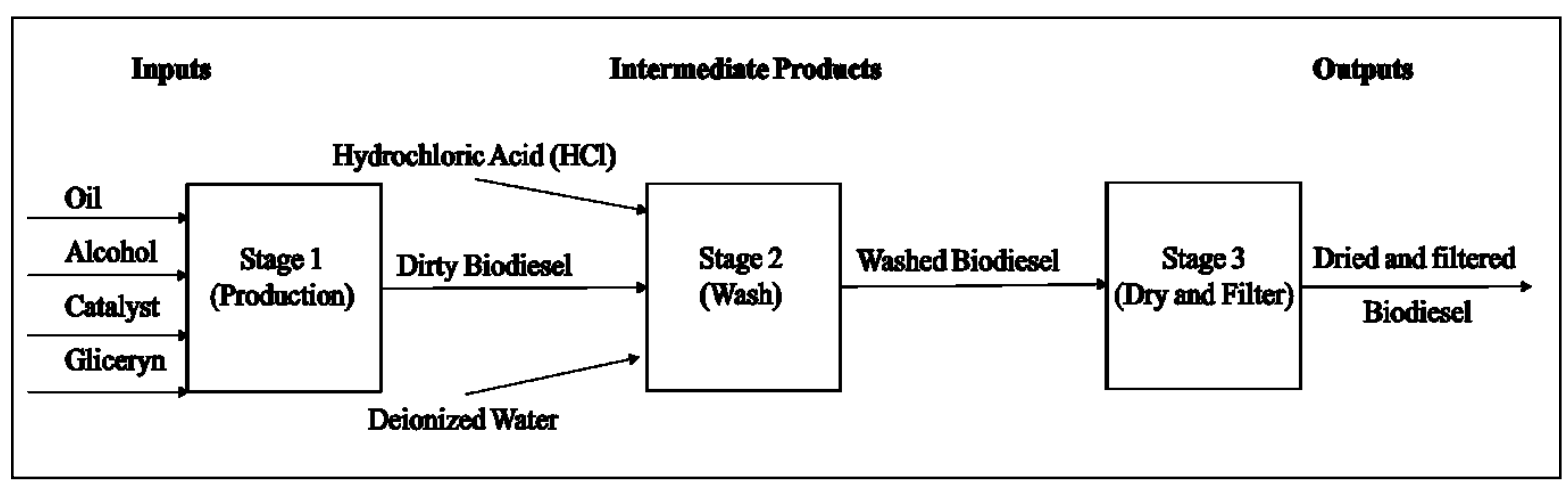

In the Equations 13 to 19 is presented the mathematical model used in this study, based on Kao and Hwang (2008).

$$
E_{0}=\min \sum_{i=1}^{4} x_{i 0} v_{i}+\sum_{d=1}^{2} z_{d 0} w_{d}
$$

s.a. 
$y_{10} u_{1}=1 j=1, \ldots, 16$

$y_{1 j} u_{1}-\sum_{i=1}^{4} x_{i j} v_{i}-\sum_{d=1}^{2} z_{d j} w_{d} \leq 0 j=1, \ldots, 16$

$c_{1 j} f_{1}-\sum_{i=1}^{4} x_{i j} v_{i} \leq 0 j=1, \ldots, 16$

$e_{1 j} g_{1}-\sum_{d=1}^{2} z_{d j} w_{d}-c_{1 j} w_{1} \leq 0 j=1, \ldots, 16$

$y_{1 j} u_{1}-e_{1 j} g_{1} \leq 0 j=1, \ldots, 16$

$u_{1} \geq \varepsilon ; v_{i} \geq \varepsilon, \forall i ; w_{d}, \forall d \geq \varepsilon ; g_{1} \geq \varepsilon ; f_{1} \geq \varepsilon$

Where ' $u_{1} ; v_{i}, w_{d}, g_{1} e f_{1}$ ' are the variables multipliers ' $y_{1 j} ; x_{i j} ; z_{d j} ; e_{1 j} e c_{1 j}$ ', respectively. $' i$ ' is the number of variables at the first stage, ' $d$ ' is the number of exogenous inputs in the second stage and ' $j$ ' is the DMU total number.

The individual efficiencies of the DMU in stages 1, 2 and 3 are given by Equations 20, 21 e 22 respectively, while the overall efficiency is calculated by the inverse of the score obtained by the software LINDO, i.e. $\frac{1}{h}$ (due to the output orientation). This procedure was adopted because the model has exogenous inputs in the second stage, thus it is no longer multiplicative.

$$
\begin{aligned}
& E_{0}^{1}=\frac{c_{10} f_{1}^{*}}{\sum_{i=1}^{4} x_{i 0} v_{i}^{*}} \\
& E_{0}^{2}=\frac{e_{10} g_{1}^{*}}{\sum_{d=1}^{2} z_{d 0} w_{d}^{*}+c_{10} f_{1}^{*}} \\
& E_{0}^{3}=\frac{y_{10} u_{1}^{*}}{e_{10} g_{1}^{*}}
\end{aligned}
$$

The LINDO 6.1 software was used for data analysis processing of the Network DEA model. 


\section{RESULTS AND DISCUSSION}

The results of the application are shown at the Table 1. The second column identifies the DMU in analysis, i.e. the oils and volume variation of these oils: soy (S), canola (A), sunflower (F), and corn (C). The following columns present the efficiency values obtained in each phase as well as overall efficiency.

Table 1- Results of the Network DEA method applied

\begin{tabular}{l|c|c|c|c|c}
\hline $\begin{array}{l}\text { DMU } \\
\text { Number }\end{array}$ & $\begin{array}{c}\text { DMU } \\
\text { Kind }\end{array}$ & Global Efficiency & Stage 1 Efficiency & Stage 2 Efficiency & $\begin{array}{c}\text { Stage 3 } \\
\text { Efficiency }\end{array}$ \\
\hline $\mathbf{1}$ & S50 & 0.882910213 & 0.955859227 & 0.942346111 & 0.93721614 \\
\hline $\mathbf{2}$ & S100 & 0.833222931 & 1 & 0.851192356 & 0.97887019 \\
\hline $\mathbf{3}$ & S200 & 0.926693881 & 0.881257593 & 0.999985121 & 0.92988065 \\
\hline $\mathbf{4}$ & S400 & 0.927673043 & 0.845568859 & 0.975632062 & 0.96061584 \\
\hline $\mathbf{5}$ & A50 & 0.934557604 & 0.9998330767 & 0.992823518 & 0.94134732 \\
\hline $\mathbf{6}$ & A100 & 0.88400994 & 0.931005732 & 0.958115014 & 0.92354529 \\
\hline $\mathbf{7}$ & A200 & 0.968383255 & 0.934279022 & 0.98018585 & 0.97981026 \\
\hline $\mathbf{8}$ & A400 & 0.941887429 & 0.880280026 & 0.964230563 & 0.98177832 \\
\hline $\mathbf{9}$ & F50 & 0.915127422 & 0.9999980173 & 0.940194322 & 0.9161666 \\
\hline $\mathbf{1 0}$ & F100 & 0.784497082 & 0.922329969 & 0.967475198 & 0.95397172 \\
\hline $\mathbf{1 1}$ & F200 & 0.924271651 & 0.917800263 & 0.96603438 & 0.95893942 \\
\hline $\mathbf{1 2}$ & F400 & 0.93721942 & 0.974776361 & 0.960116286 & 0.97746617 \\
\hline $\mathbf{1 3}$ & C50 & 0.929768971 & 0.983742895 & 0.981231956 & 0.95066759 \\
\hline $\mathbf{1 4}$ & C100 & 0.957671861 & 0.934161679 & & 1 \\
\hline $\mathbf{1 5}$ & C200 & 0.886108477 & 0.913144438 & 0.912353627 & 0.97358373 \\
\hline $\mathbf{1 6}$ & C400 & 0.937969278 & 0.9507101 & 0.960443698 & 0.97991102 \\
\hline
\end{tabular}

In order to find the efficiency scores of each stage, it was used the equations 3.1 to 3.3. Although for the global score it is not possible to use the equation 3.4, because since the applied model has exogenous inputs in the second stage, it is no longer multiplicative. For this reason, the overall efficiency score is obtained by the inverse of the LINDO software score.

With all the DMU evaluation results summarized in the Table 1, it can be observed that no DMU has achieved the maximum efficiency because in this case the efficiency is given by the inefficiency of the considered DMU, when the maximum efficiency is obtained at some stage. As mentioned before, a unit is considerable efficient by the Network DEA models, when it is efficient at all stages. These values aim to create a DMU here evaluated ranking. Considering this, the model obtained a discriminatory result, in consequence of a non-fully efficient DMU.

For stage 1, the maximum efficiency was $100 \%$ and minimum of $84.55 \%$. The model presented 5 DMU that have their best performance in stage 1: Soy $50 \mathrm{ml}$, Soy $100 \mathrm{ml}$, Canola $50 \mathrm{ml}$, Sunflower $50 \mathrm{ml}$ and Corn $50 \mathrm{ml}$. The first stage corresponds to the biodiesel production through the transesterification reaction. It is affirmable that first stage performance is related to the reaction conditions, i.e., the ratio between alcohol / oil, the type and quantity of catalyst, the reactions time and temperature, the rotations intensity and reagents quality (free fatty acid and triglyceride water content). The transesterification reaction is conducted under mechanical agitation. Such stirring is necessary to improve the mass transfer, which is hampered by the low oil / alcohol miscibility. Besides the reaction conditions, the raw material quality is a fundamental parameter for the 
reaction viability. High temperatures exposure and the moisture presence accelerates the triglycerides hydrolysis and the free fatty acids formation. Under the conditions presented at the first stage, the volumes of $50 \mathrm{ml}$ and $100 \mathrm{ml}$ have presented better efficiency.

The stages 2 and 3 are purification ones. The second stage is the washing step, where it is performed to neutralize the remaining catalyst and break any soap that may have been formed. It has presented $100 \%$ of maximum and $85.11 \%$ of minimum efficiency. The rinsing of crude biodiesel is related to the inefficiencies of this stage. This can also be verified in acidified water washings, that range from $81 \%$ to $98 \%$ of efficiency, with significant losses observed during the purification process. These results indicate that the basic catalyst reacted with the free fatty acids producing water-soluble soaps, which were removed in this drying step, decreasing furthermore the yield.

It is noteworthy that the sodium hydroxide / alcohol reaction leads to the water formation and, in the presence of the basic catalyst, may lead to some ester hydrolysis and consequently soap formation. This undesirable saponification reduces the ester yield and considerably hinders the glycerol recovery, due to the emulsion formation. Besides, the catalyst consumption reduces the reaction efficiency, resulting in purification difficulties, emulsions formation and yield losses. Therefore, for base catalyzed transesterification, both oils or fats and alcohol must be water free (GERIS, 2007).

After washing, the biodiesel goes through a drying step, where the biodiesel is heated, in order to remove moisture traces. The third stage has a maximum efficiency of $98.17 \%$ and a minimum of 91.61\%. Overall, the DMU have well performed at this stage. The inefficiencies in stage 3 are consequences of inefficiencies in stage 2, because all the water or soap formed in the washing process will be eliminated during drying step.

Analyzing the DMU global stage with the lower volumes and larger volumes, there is a raising scale return for the four different oils. In other words, when the reagents volume increases, the biodiesel production and DMU efficiency also increase, according to Table 2.

Table 2 - Global Efficiency and Scale Factor

\begin{tabular}{|c|c|c|c|}
\hline Oil Kind & DMU & Global Efficiency & Scale Factor \\
\hline \multirow{2}{*}{ Soy } & S50 & 0.882910213 & \multirow{2}{*}{ Raising } \\
\hline & S400 & 0.927673043 & \\
\hline \multirow{2}{*}{ Canola } & A50 & 0.934557604 & \multirow{2}{*}{ Raising } \\
\hline & A400 & 0.941887429 & \\
\hline \multirow{2}{*}{ Sunflower } & F50 & 0.934557604 & \multirow{2}{*}{ Raising } \\
\hline & F400 & 0.93721942 & \\
\hline \multirow{2}{*}{ Corn } & C200 & 0.929768971 & \multirow{2}{*}{ Raising } \\
\hline & C400 & 0.937969278 & \\
\hline
\end{tabular}




\section{CONCLUSIONS}

For all DMU process was obtained the global efficiency. It has been found none fully efficient DMU. The maximum score for overall efficiency occurred in Canola oil with a volume of $200 \mathrm{~mL}$ (DMU 7), reaching $96.83 \%$ and the lowest performance was observed in the Sunflower oil with volume of $100 \mathrm{~mL}$ (DMU 10) that achieves only $78.44 \%$. It was observed at the first stage, the crude biodiesel production process, the greater variation among the DMU. The most efficient DMU at this stage was the Soy 100mL (DMU 2), which contradictory was one of the least efficient DMU at the global stage.

Considering the global scale, it was observed a raising scale factor, for all kinds of oil. When the input volumes (reagents) increase, the output (biodiesel) volume also increase and it is observed an efficiency improvement.

\section{REFERENCES}

AGÊNCIA NACIONAL DO PETRÓLEO, GÁS NATURAL E BIOCOMBUSTÍVEIS - ANP. Resolução ANP № 45 de 25/8/2014. Estabelece a especificação do biodiesel e as obrigações quanto ao controle da qualidade a serem atendidas pelos diversos agentes econômicos que comercializam o produto em todo o território nacional. Disponível em: $<$ http://www.anp.gov.br/wwwanp/movimentacao-estocagem-e-comercializacao-de-gasnatural/transporte-de-gas-natural/acesso-a-gasodutos/766-producao-de-biocombustiveis-3> . Acesso em: 05 de agosto de 2017.

CHARNES, A.; COOPER, W. W.; RHODES, E. Measuring the efficiency of decision making units. European Journal of Operational Research, North Holland, v. 2, n. 6, p. 429-444, 1978.

CHARNES, A.; COOPER, W. W. The non-archimedean CCR ratio for efficiency analysis: A rejoinder to Boyd and Fare. European Journal of Operational Research, North Holland v. 15, n. 3, p. 333-334, 1984.

COSTA NETO, P. R.; ROSSI, F. S. L.; ZAGONEL, G. F.; RAMOS, L. P. Produção de biocombustível alternativo ao óleo diesel através da transesterificação de óleo de soja usado em frituras. Química Nova, São Paulo, v. 23, n. 4, p. 531-537, 2000.

DE CASTRO LOBO, M. S.; LINS, M. P. E.; SILVA, A. C. M.; FISZMAN, R. Avaliação de desempenho e integração docente-assistencial nos hospitais universitários. Revista de Saúde Pública, São Paulo, v. 44, n. 4, p. 581-590, 2010.

FARRELL, M. J. The Measurement of Productive Efficiency. Journal of the Royal Statistical Society, United Kingdom, v. 120, n. 3, p. 253, 1957. 
FERRARI, R. A.; OLIVEIRA, S. Biodiesel de soja - taxa de conversão em ésteres etílicos, caracterização físico-química e consumo de energia. Química Nova, São Paulo, v. 28, n. 1, p. 19-23, 2005.

GERIS, R.; SANTOS, N. A. C.; AMARAL, B. A.; MAIA, I. S.; CASTRO, V. D.; CARVALHO, J. R. M. Biodiesel de Soja - Reação de Transesterificação para Aulas Práticas de Química Orgânica. Química Nova, São Paulo, v. 30, p.1369-1373, 2007.

GOMES JÚNIOR, S. F.; SOARES DE MELLO, J. C. C. B. Utilização de Modelo Network DEA na Avaliação de Cursos de Pós-Graduação Stricto Sensu em Engenharia. Anais do XVII Simpósio de Pesquisa Operacional e Logística da Marinha - SPOLM 2014, 2014.

GRIMALDI, R.; GONÇALVES L. A. G.; ANDO, M. Y. Otimização da reação de interesterificação química do óleo de palma. Química Nova, São Paulo, v. 28, n. 4, p. 633-636, 2005.

KAO, C.; HWANG, S. N. Efficiency decomposition in two-stage data envelopment analysis: An application to non-life insurance companies in Taiwan. European Journal of Operational Research, North Holland, v. 185, p. 418-429, 2008.

KARMAKAR, A.; KARMAKAR, S.; MUKHERJEE, S. Properties of various plants and animals feedstocks for biodiesel production. Bioresource Technology, United Kingdom, v. 101, n. 19, p. 7201-7210, 2010.

LIMA, J. R. O.; SILVA, R. B.; SILVA, C. C. M.; SANTOS, L. S. S.; DOS SANTOS JÚNIOR J. R.; MOURA, E. M.; MOURA, C. V. R. Biodiesel de babaçu. Química Nova, São Paulo, v. 30, n. 3, p. 600-603, 2007.

LIN, C. Y.; LIN, H. A.; HUNG, L. B. Fuel structure and properties of biodiesel produced by the peroxidation process. Fuel, United Kingdom v. 85, n. 12-13, p. 1743-1749, 2006.

LORA, E. E. S.; VENTURINI, O. J. Biocombustíveis: Volume 1. Interciência, Rio de Janeiro, v.1,2012.

MATH, M. C.; PREM, S.; CHETTY, S. V. Energy for Sustainable Development Technologies for biodiesel production from used cooking oil - A review. Energy for Sustainable Development, United Kingdom, v. 14, n. 4, p. 339-345, 2010.

MENEGHETTI, S. M. P.; MENEGHETTI, M. R.; WOLF, C. R.; SILVA, E. C.; LIMA, G. E. S.; SILVA, L. L.; SERRA, T. M.; CAUDURO, F.; OLIVEIRA, L. G. Biodiesel from Castor Oil : A Comparison of Ethanolysis versus Methanolysis. Energy and Fuels, Washington, n. 5, p. 2262-2265, 2006.

OLIVEIRA, S. M. M.; COSTA, B., J. Produção de biodiesel. Dossiê técnico. Instituto de Tecnologia do Paraná, 2006.

REDÁ, S. Y.; CARNEIRO, P. I. B. Óleos e gorduras: aplicações e implicações. Analytica, Rio de Janeiro, v. 27, p. 60, 2007. 
SANTACESARIA, E.; VICENTEB, G. M.; DI SERIOA, M.; TESSERET, R. Main technologies in biodiesel production: State of the art and future challenges. Catalysis Today, United Kingdom, v. 195, n. 1, p. 2-13, 2012.

SANTOS, M. F. V.; GODIM, A. D.; OlIVEIRA, T. P.; PEIXOTO, C. G. D.; BATISTA, A. C. M.; FERNANDES JUNIOR, V. J. PRODUÇÃO DE BIODIESEL POR TRANSESTERIFICAÇÃO UTILIZANDO CATALISADOR HETEROGÊNEO (KOH/Al2O3). Holos, Rio Grande do Norte, v. 1, p. 241, 2017.

SCHEEL, H. Undesirable outputs in efficiency valuation. European Journal of Operational Research, United Kingdom, v. 132, p. 400 - 410, 2001.

SCHUCHARDT, U.; SERCHELI, R.; MATHEUS, R. Transesterification of Vegetable Oils : a Review General Aspects of Transesterification Transesterification of Vegetable Oils Acid-Catalyzed Processes Base-Catalyzed Processes. Journal of Chemistry Society, United Kindom, v. 9, n. 1, p. 199-210, 1998.

SILVA, P. R. F. DA; FREITAS, T. F. S. DE. Biodiesel: o ônus e o bônus de produzir combustível. Ciência Rural, Santa Maria, v. 38, n. 3, p. 843-851, 2008.

SORDA, G.; BANSE, M.; KEMFERT, C. An overview of biofuel policies across the world. Energy Policy, United Kingdom, v. 38, n. 11, p. 6977-6988, 2010.

XIE, W.; LI, H. Alumina-supported potassium iodide as a heterogeneous catalyst for biodiesel production from soybean oil. Journal of Molecular Catalysis, United Kingdom, v. 255, p. 1-9, 2006.

ZAGONEL, G. F.; RAMOS, L. P. Produção de biocombustível alternativo ao óleo diesel através da transesterificação de óleos vegetais. Revista de Química Industrial, Rio de Janeiro, v. 39, p. 717, 2001. 